\title{
Petroleum system modeling in cenozoic sediments, Block 05-1a, Nam Con Son Basin
}

\author{
Xuan Van Tran, Huy Nhu Tran, Chuc Dinh Nguyen, Tuan Nguyen, Ngoc Ba Thai \\ Kha Xuan Nguyen, Thanh Quoc Truong, Trung Hoang Quang Phi, Minh Bao Luong
}

\begin{abstract}
Based on the update of exploration data the oil and gas potential within block 05-1 are studied through define the source rocks, Hydrocarbon (HC) generation, expulsion and migration, focusing on source rock Oligocene /Early Miocene and Middle Miocene; Define the accumulation of hydrocarbon in Lower Miocene targets; The results of assessments for source rock, oil sampling analysis is used to determine the relationship between in-situ oil or oil migrated from other places. The workflow of basin modeling is assigned to get output (migration pathways, volume of accumulation), as well as data calibration. Main source rocks include H150, H125 shales and H150 coal with Total organic carbon (TOC) 1 and 47 respectively. These source rocks are medium to good potential. At the present time, most of the source rocks are in oil window, while the deep parts is in gas window. Oil started to be generated in Early Miocene, and started to be expulsed in Late Miocene. Gas started to be generated in Quaternary, about to be expulsed. The oil migrated mainly from the troughs at the West and minorly from the East and South to Dai Hung High. Gas started to migrate from West to East and South West to North East at the Western part. However, at the Eastern part, gas migrated from the opposite direction. The results of sensitive analyses show more oil in max source rock case, therefore, a 3D model development is
\end{abstract}

Manuscript Received on August 7th, 2017. Manuscript Revised December 25th, 2017.

The authors thank to PetroVietnam Exploration Production Corporation for the support and permission to publish this work. Contributing technical assistance and comments for this manuscript from Ho Chi Minh City University of Technology VNU-HCM and PetroVietnam Domestic Exploration Production Operating Company Colleagues are greatly acknowledged and appreciated.

Xuan Van Tran, Tuan Nguyen, Ngoc Ba Thai, Kha Xuan Nguyen, Thanh Quoc Truong, Trung Hoang Quang Phi, Minh Bao Luong, are with Department of Petroleum Geology, Faculty of Geology and Petroleum Engineering, Ho Chi Minh City University of Technology - VNU-HCM.

Huy Nhu Tran - PetroVietnam Domestic Exploration Production Operating Company Ltd)

Chuc Dinh Nguyen - PetroVietnam Domestic Exploration Production Operating Company Ltd (e-mail: ndchuc1977@gmail.com)

* Corresponding author: Email: tvxuan@hcmut.edu.vn recommended and identify the differences in generation characteristics between Nam Con Son and Cuu Long basins.

Index Terms-Modeling, seismic interpretation, petroleum system, migration, hydrocarbon accumulation.

\section{INTRODUCTION}

$\mathrm{D}$ ai Hung oil field is located in Block 05.1a, Nam Con Son (NCS) basin. Up to now, Dai Hung (DH) oil field has 37 exploration/appraisal and production wells and 4 wells are ThN-1X and DHN-1X, 2X, 3X which locate outside of field area (Figure 1). The main objectives of this study are to re - assessment the petroleum system in block 05.1a and propose the upcoming exploration strategy [1].

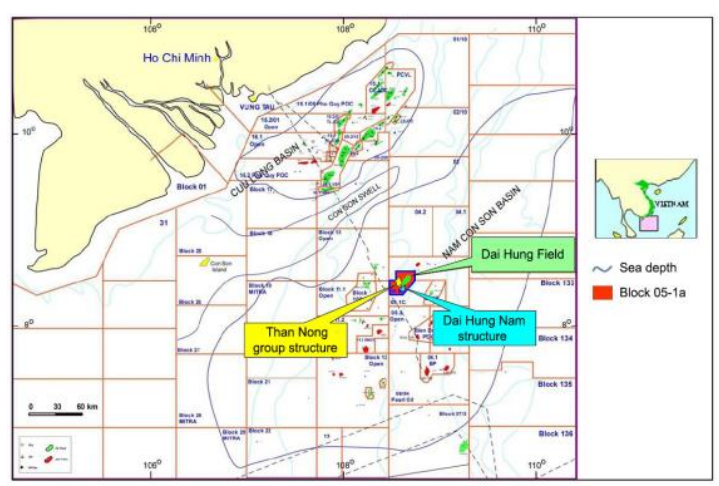

Figure 1. Location of block 05-1a [1]

The 3D geochemical model is conducted based on interpretation of well data, seismic data in block 05.1a and surrounding areas as well as evaluation of the potential for oil and gas in NCS basin within previous studies. This research included 2 phases: Collecting and updating the data of previous studies; Updating the seismic data outside of DH oil field, extending to the regional cluster as Than 
Nong (ThN) and Dai Hung Nam (DHN) structures; 3D geochemical modeling for $\mathrm{DH}$ oil field, extending to the entire block 05.1a and surrounding areas. Model results will be used to estimate oil and gas potential, migration potential, accumulation for each structure, as well as assess the remain risks [1].

\section{METHODOLOGY AND IMPLEMENTATION PROCESS}

\subsection{The methodology}

Assessment for source rock: Overview of source rock within NCS basin, evaluating the richness of source rock, estimating the source rocks' quality, developing variation chart of Kerogen and Ro versus depth. Determining the relationship between oil and oil: for classification / comparison between in-situ oil or oil migrated from other places (based on oil sample analysis results) [2]; 3D geochemical modeling in researched area, identifying the hydrocarbon generation potential, migration, accumulation of oil and gas, Assessing the correlation characteristics of PVT parameters. The appropriate software: IP, Geo Frame/ Petrel, PetroMod/Petrel are used to determining the thickness of source rock, reservoir, seal; seismic interpretation; 2D, 3D geochemical modeling respectively.

\subsection{Implementation process}

2.2.1 Basin modeling workflow: Based on input data and range of study, the basin is modeled by following workflow (Figure 2).

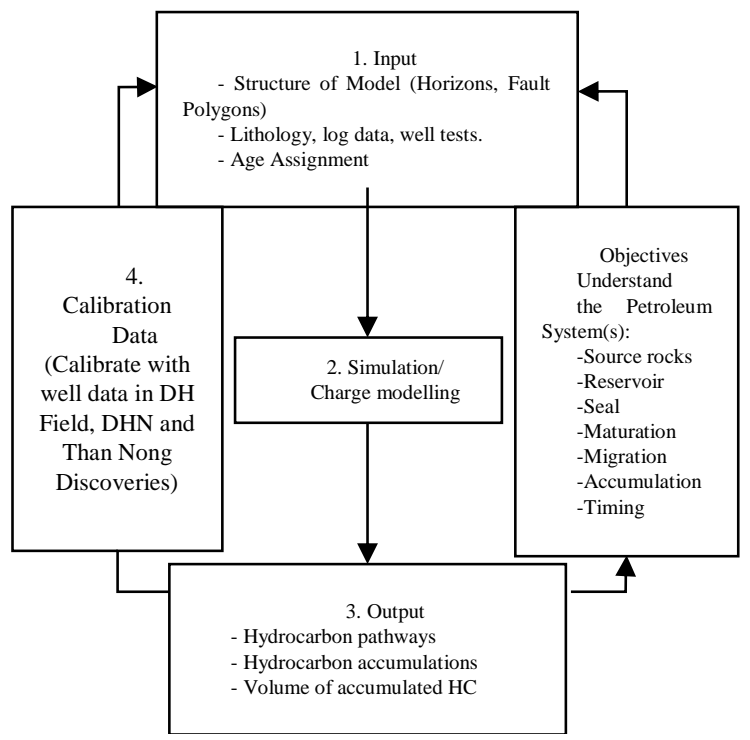

Figure 2. Work flow of basin modeling

\subsubsection{Input parameters}

Source rock parameter input: Based on the geochemical data of DH wells, the source rocks (SR) of the study area are determined as H150 Shale SR (Oligocene), H150 Coal SR (Oligocene), and H125 Shale SR (Early Miocene) [3]. The H150-H200 SRs including claystone, coaly claystone and coal are main source rocks in area. Kerogen is mainly types III/II and maturity (oil window). The H80-H150 SRs include claystone, silty claystone, coal and coaly claystone. The maturity of H125-H150 SR is mainly in oil and gas generation window while $\mathrm{H} 80-\mathrm{H} 125$ is mainly immature.

Reservoir parameter input: The reservoirs of $\mathrm{H} 80$ and H100 are used because they are main clastic reservoirs in DH field, where a great amount of hydrocarbon has been produced and found.

The depth of H100 reservoir is from 2,100 $5,450 \mathrm{mss}$. The porosity of this reservoir is from 4 $17.5 \%$, good porosity is located inside the red ring, $>13 \%$ (Figure 2), and similar to the porosity from well logs $(13-18 \%)$.

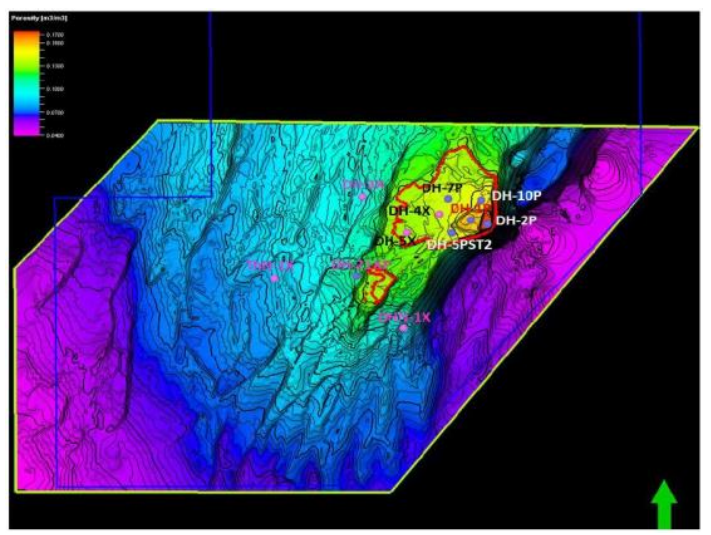

Figure 3. H100 Reservoir porosity map [4]

The depth of H80 reservoir is from 1,750 $4,600 \mathrm{mss}$. The porosity of this reservoir is from $6-$ $21 \%$, good porosity is located inside the red ring (>15\%), Figure 3 ), and similar to the porosity from well logs $(13-21 \%)$. 


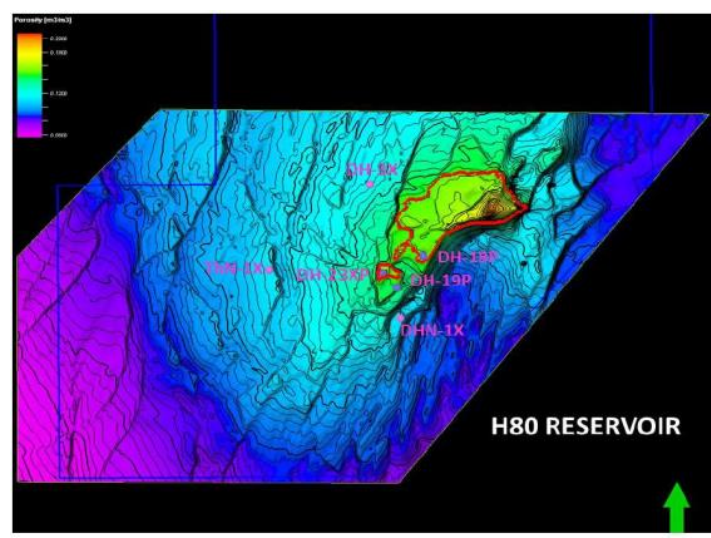

Figure 4. H80 Reservoir porosity map [4]

Seal parameter input

The top seal quality of $\mathrm{H} 100$ is from good to very good (capillary pressure from 11.5-18.7 bar) (Figure 4). The top seal quality of H80 is good (capillary pressure from 9.5-14.9 bar) (Figure 5).

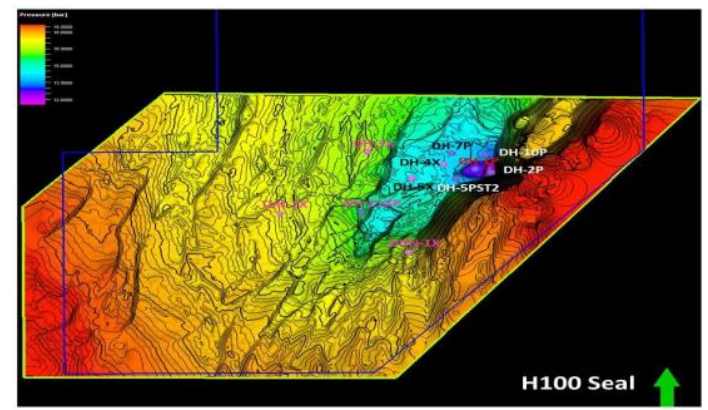

Figure 5. H100 Seal capillary pressure map [4]

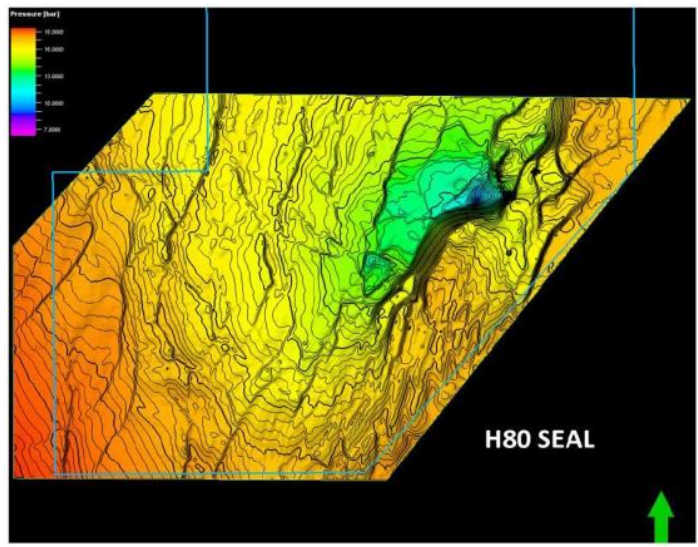

Figure 6. H80 Seal capillary pressure map [4]

Simulation: Pressure-Temperature modeling: Temperature is simulated based on the upper boundary condition determined as the surface (seafloor) temperature, the basement heat flow at the lower boundary of the model, and the thermal conductivity of all layers in the model. For pressure modeling, various compaction laws can be modeled as defined in the lithologies and pressure boundary conditions can be assigned to account. Petroleum generation: Based on database of reaction kinetics, the phases and properties of hydrocarbons generated from source rocks of various types will be predicted. The models also describe the release of generated hydrocarbons into the free pore space of the source rock. Furthermore, the number of chemical components produced in this model can vary between 2 (oil and gas) and 20. Migration modeling: The 2D, 3D migration modeling technology uses flash calculations throughout the entire model and its geologic history, which improves the understanding and prediction of petroleum properties and oil versus gas probability assessments. Migration velocities and accumulation saturations are calculated in one step. Describing fluid migration across faults requires special algorithms.

In the block05-1a area, the P-T, petroleum generation and migration modeling is bounded by horizons from $\mathrm{H} 80$ to $\mathrm{H} 200$.

Charge modeling input data: Source rocks: H150 Coal (TOC $=47$, Average Thickness $\sim 2 \mathrm{~m}$ ), H150 Shale $(\mathrm{TOC}=1$, Average thickness $=20-30 \mathrm{~m}$, H125 Shale (TOC $=1$, Average Thickness $\sim 20 \mathrm{~m}$ ). Reservoir: $\mathrm{H} 100$ and Seal: H100.

\section{MODELING RESULTS}

The result of 2-D model will be shown in maturation, generation \& expulsion timing, generated hydrocarbon mass, gas transformation ratio, migration pathway \& accumulation in reservoir, as well as sensitive analysis.

\section{$3.1 \quad$ Maturation maps}

MATURATION MAP OF H150 SOURCE ROCK (SHALE)

\begin{tabular}{|c|c|c|c|}
\hline $\begin{array}{c}\text { Source } \\
\text { rock type }\end{array}$ & $\begin{array}{c}\text { Mature } \\
\text { window (\%) }\end{array}$ & $\begin{array}{c}\text { Oil window } \\
(\%)\end{array}$ & $\begin{array}{c}\text { Wet gas } \\
\text { window (\%) }\end{array}$ \\
\hline III & $\sim 15$ & $\sim 55$ & $\sim 30$ \\
\hline
\end{tabular}




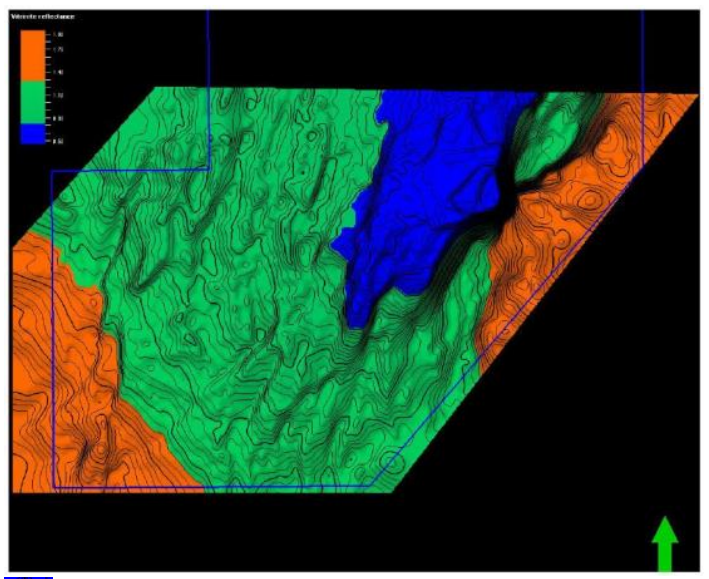

Mature window

Oil window

Wet gas window

Figure 7. Maturation map of H150 SR (shale)

This output is based on TOC input as $0.96 \%$ and HI of 244.

\section{MATURATION MAP OF H150 SOURCE ROCK} (SHALE)

\begin{tabular}{|c|c|c|c|}
\hline $\begin{array}{c}\text { Source } \\
\text { rock type }\end{array}$ & $\begin{array}{c}\text { Mature } \\
\text { window } \\
(\%)\end{array}$ & $\begin{array}{c}\text { Oil window } \\
(\%)\end{array}$ & $\begin{array}{c}\text { Wet gas } \\
\text { window }(\%)\end{array}$ \\
\hline III & $\sim 15$ & $\sim 55$ & $\sim 30$ \\
\hline
\end{tabular}

This output is based on TOC input as $47 \%$ and HI of 298, due to low organic matter content and over maturation range hence it is not classified as source rock.

MATURATION MAP OF H125 SOURCE ROCK (SHALE)

\begin{tabular}{|c|c|c|c|}
\hline $\begin{array}{c}\text { Source } \\
\text { rock type }\end{array}$ & $\begin{array}{c}\text { Mature } \\
\text { window } \\
(\%)\end{array}$ & $\begin{array}{c}\text { Oil window } \\
(\%)\end{array}$ & $\begin{array}{c}\text { Wet gas } \\
\text { window (\%) }\end{array}$ \\
\hline III & $\sim 25$ & $\sim 55$ & $\sim 20$ \\
\hline
\end{tabular}

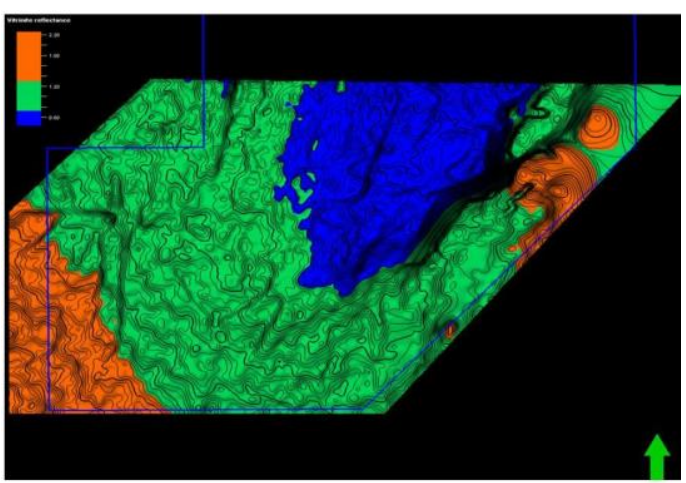

Figure 8. Maturation map of H125 Shale SR
This output is based on TOC input as $0.95 \%$ and HI of 231.

\subsection{Source rock timing and generated hydrocarbon volume:}

H150 Shale SR: The time for the H150 shale SR in study area started to enter the main oil window was approximately $13 \mathrm{Ma}$ in Middle Miocene (Figure 9). Most of the study area were in the main oil window in Late Miocene (green zone) while the area in yellow is in oil production in Quaternary.

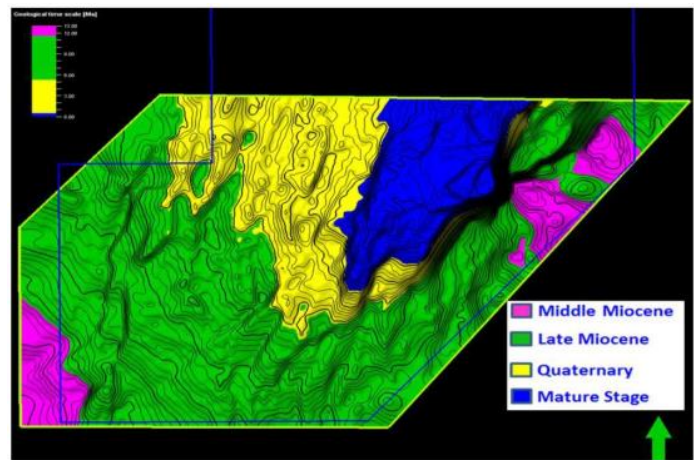

Figure 9. Main oil window generation timing of H150 Shale S

The oil only pushed out of the source rock if the oil transformation $>50 \%$ (outside red ring, Figure 10). Oil produced from the deep part (yellow and green zone) has been expulsed where the oil from depth lower 4,800 mss (green zone) primarily migrated in Late Miocene and oil from 4,8004,100 mss (yellow zone) started to move in Quaternary. The oil produced from the upper part (from 4,100 mss) properly still stays in the SR.

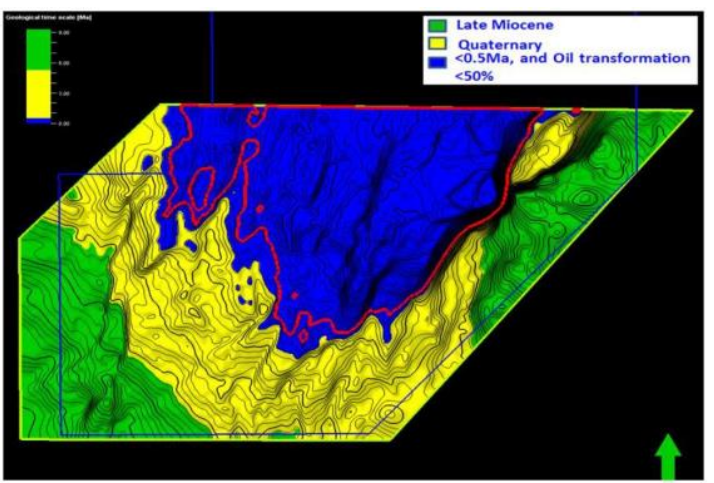

Figure 10. Oil expulsion timing of H150 Shale SR 
The model result outlines the vertical window of oil migration timing. Oil from Oligocene Shale S.R in depth below 4,800mss section would be expulsed from Late Miocene while those in 4,100$4,800 \mathrm{mss}$ interval started to migrate in Quaternary. Oil in sequence above $4,100 \mathrm{mss}$ has not been expulsed from SR yet.

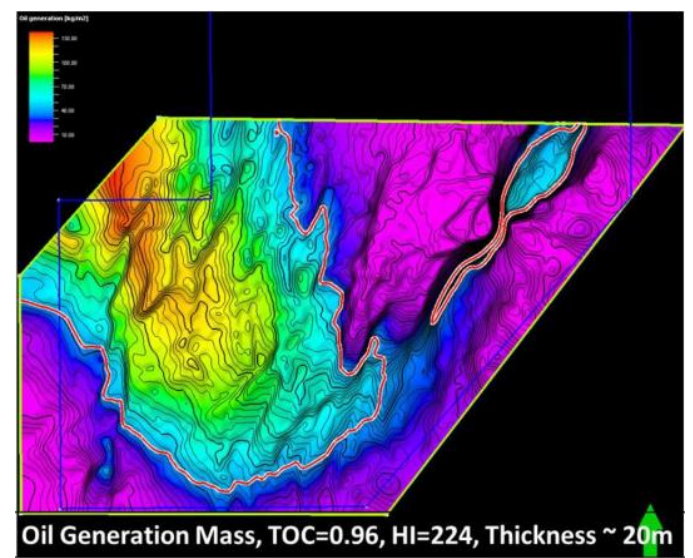

Figure 11. H150 Shale SR Oil generation mass

A mass of oil produced $/ \mathrm{m}^{2}$ is estimated very differently from 0,5 to $138 \mathrm{~kg}$ (Figure 11), mostly from interval of $3,700-4,950 \mathrm{mss}$ where the source rock is in the main oil window (inside the red ring). The mass of gas produced is estimated from 0 to $230 \mathrm{~kg}$ (Figure 12), and mainly from below 4,300mss.

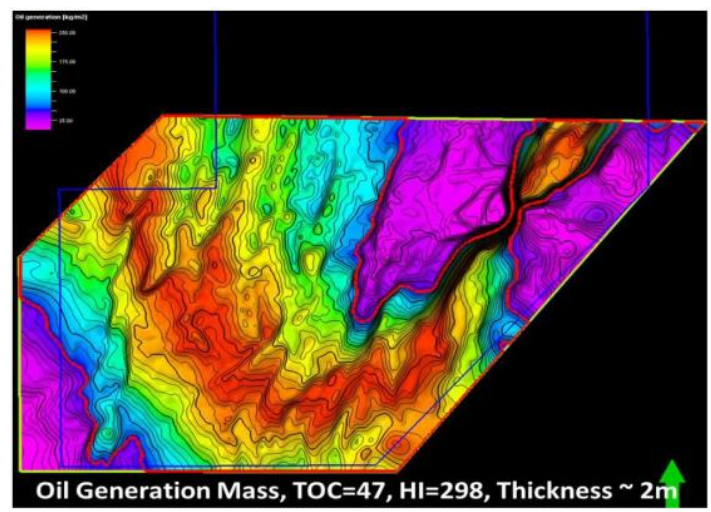

Figure 12. H150 Shale SR Gas generation mass

H150 Coal SR: The time for the H150 coal source rock in study area began to be in the main oil window was approximately $13 \mathrm{Ma}$ in Middle Miocene (Figure 13). Most of the study area were in the main oil window in Late Miocene (green zone) while the area in yellow is in oil production in Quaternary.

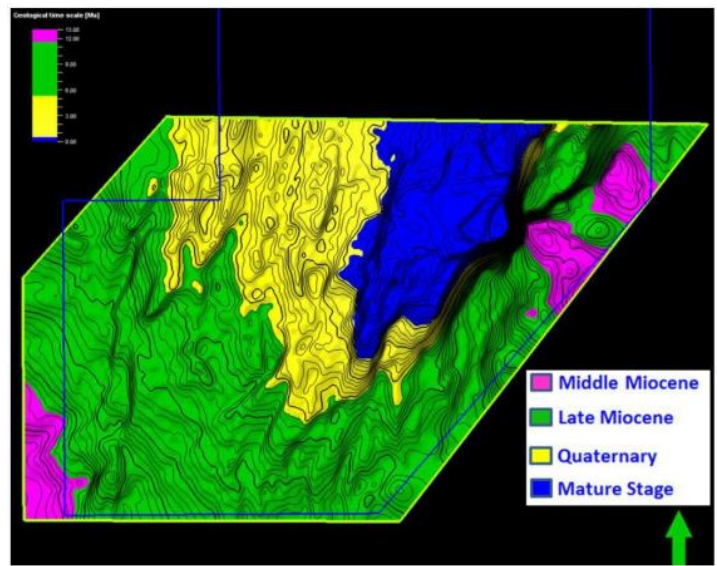

Figure 13. Main oil window generation timing of H150 Coal SR

The oil was expulsed from the source rock outside the red ring (Figure 14). Oil from Oligocene Coal SR in depth below 4,800mss section would be expulsed from Late Miocene (approx. 9.3Ma-green zone) while those in 4,100$4,800 \mathrm{mss}$ interval started to migrate in Quaternary (yellow zone), and oil in sequence above $4,100 \mathrm{mss}$ has not been expulsed from SR yet (blue zone).

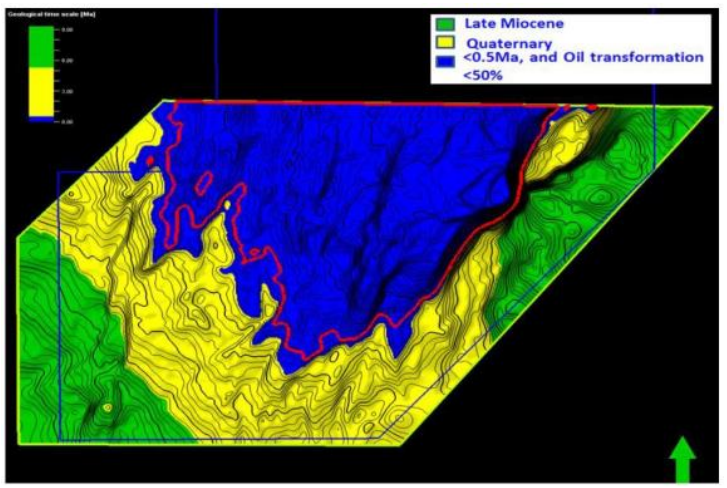

Figure 14. Oil expulsion time of H150 Coal SR

The rate of oil produced is estimated very variously from 0.5 to $138 \mathrm{~kg}$, mostly from interval of 3,700-3,350mss where the source rock is in the main oil window (inside the red ring, Figure 15). 


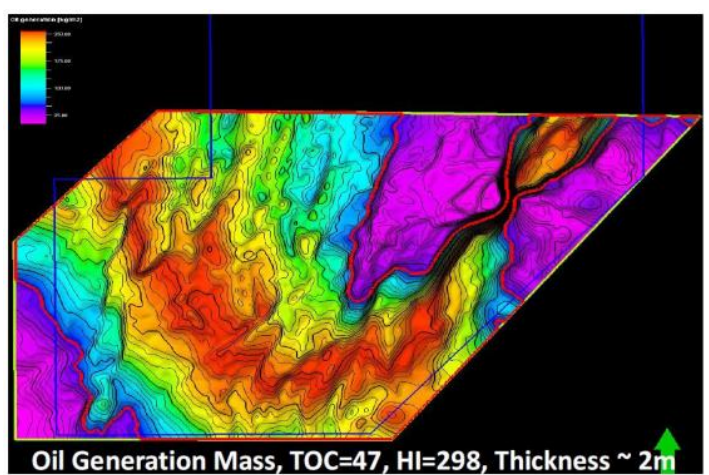

Figure 15. H150 Coal SR Oil generation mass

The mass of gas expulsed is estimated from 0 to $470 \mathrm{~kg}$, and mainly from below 4,060mss (Figure 16).

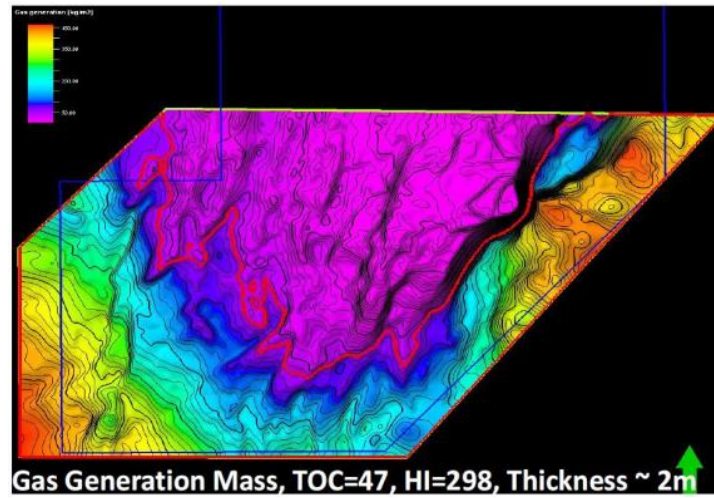

Figure 16. H150 Coal SR Gas generation mass

H125 Shale SR: Within the H125 shale SR started to enter main oil window approximately 7,5 Ma -Late Miocene (Figure 17). However, most of the area began to be cooked in the main oil window in Quaternary and about one third still does not enter this state yet. Then, the primarily migration phase from this SR could be around 5,9Ma (Late Miocene) (Figure 18). Oil expulsed in Late Miocene from H125 shale SR at depth below $5,500 \mathrm{mss}$ located at a very small section, at the edge of the South West corner (green zone) while those in 4,200-5,500mss interval started to migrate in Quaternary dominated nearly half of area (yellow part), and the biggest part is the place where oil has not been expulsed from SR yet (above 4,200mss-blue zone).

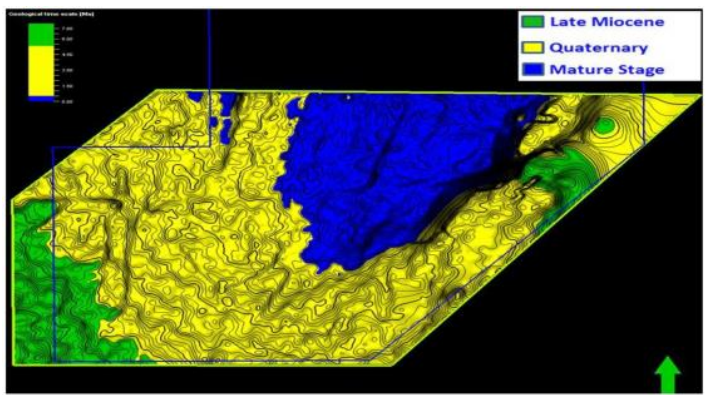

Figure 17. Main oil window generation timing of H125 Shale SR

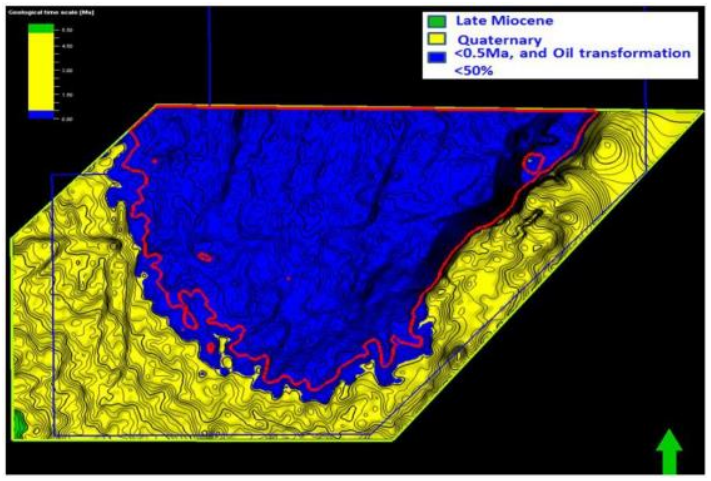

Figure 18. Oil expulsion timing from H125 Shale SR

Similar to other SRs, the H125 Shale SR also entered the Wet gas window somewhere from depth of 5,150m at approx. 0,53 to 3,2 Ma, inside the red ring. The rest of area is still not in the Wet gas window yet (Figure 19).

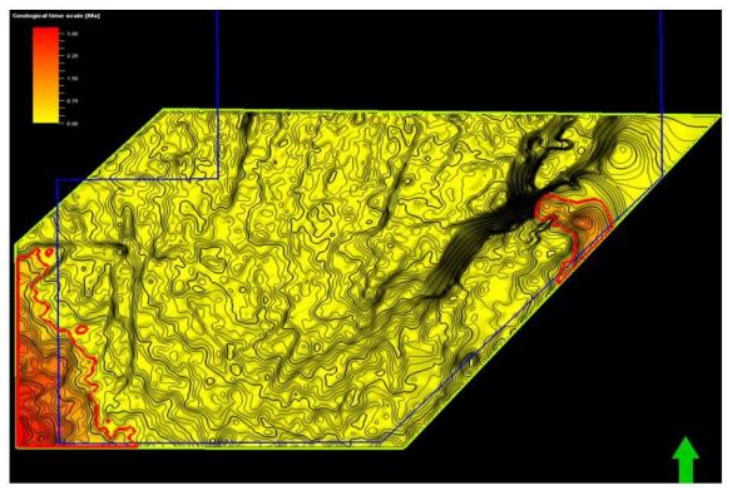

Figure 19. Wet gas window generation timing of H125 Shale SR

The mass of generated oil from the H125 Shale SR is less than the other SRs due to less time being cooked properly and estimated from 0.5 to $43 \mathrm{~kg}$, and mostly from interval of $3,700-4,000 \mathrm{mss}$ (Figure 20). While for the volume of generated gas, this number is 0,5 to $84 \mathrm{~kg}$, generally from below 4,800m (Figure 21). 


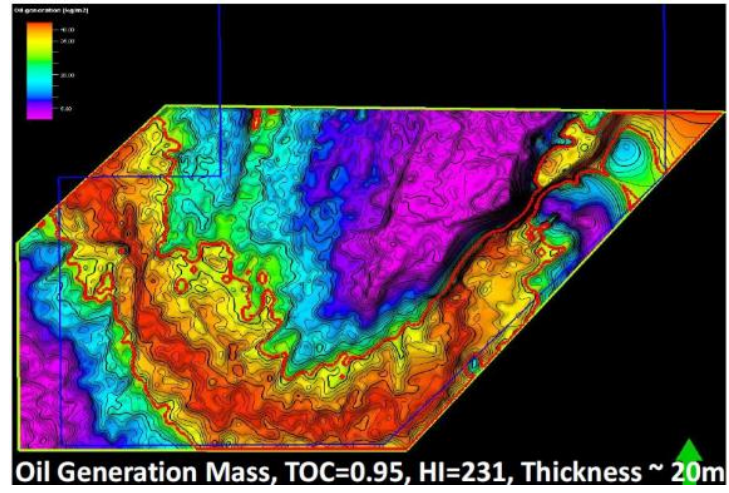

Figure 20. H125 Shale SR Oil generation mass

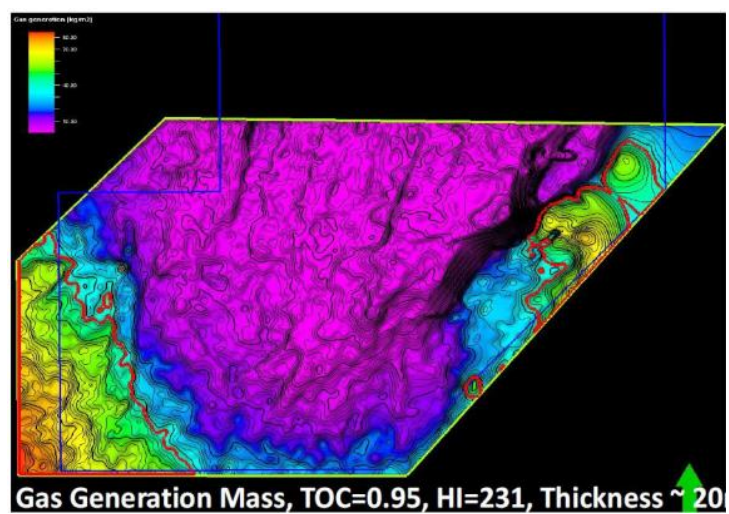

Figure 21. H125 Shale SR Gas generation mass

\subsection{Migration pathways and accumulation in reservoirs}

In $\mathrm{H} 100$ reservoir, expulsed oil migrated from the west $\&$ east troughs to DH High by both faults and carrying beds, then trapped in production reservoirs at DH field (Figure 22). The oil accumulated to Northern area (blocks K, J, L, D respectively to well DH-1P, DH-10P, DH-2P, DH$7 \mathrm{P} \&$ DH-4X; Southern area (blocks Z, T1, respectively DH-21XP, DH-23XP) as well as DHN discovery (DHN-1X). Meanwhile, there is no oil accumulation at $\mathrm{ThN}$ Discovery (ThN-1X) at H100. These phenomena are matching with the real production situation of $\mathrm{DH}$ field. However, those blocks next to block Z (B1) and South East of DHN happen to accumulate oil at H100 according to the model [4].

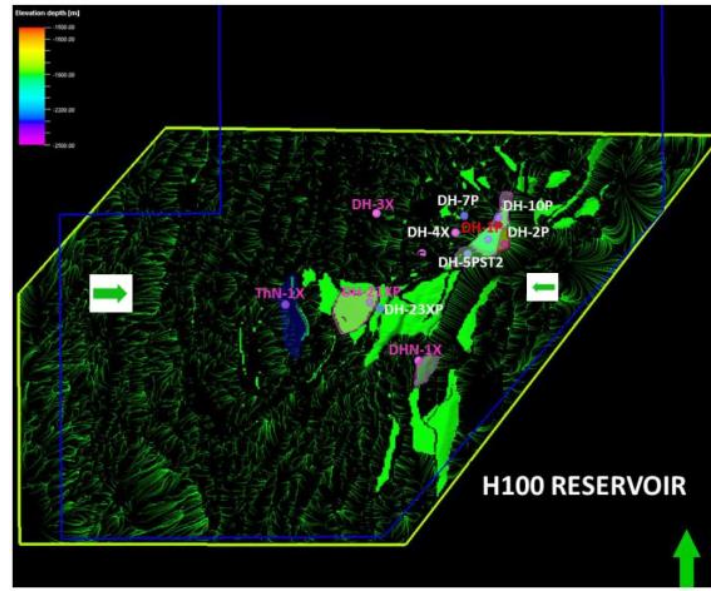

Figure 22. Migration pathway of oil into H100 reservoirs

In case of calculating accumulated $\mathrm{HC}$ at reservoirs, the model gives results as an estimate as in table below:

\begin{tabular}{|c|c|c|c|}
\hline No & Blocks & $\begin{array}{c}\text { Area } \\
\left(\mathrm{km}^{2}\right)\end{array}$ & $\begin{array}{c}\text { HCIIP } \\
(\text { MMbbls })\end{array}$ \\
\hline 1 & $\begin{array}{c}\text { Block K + } \\
\text { block J +block L }\end{array}$ & $\begin{array}{c}1.08+ \\
0.96+0.47\end{array}$ & $\sim 71$ \\
\hline 2 & Block Z & 2.9 & $\sim 73.7$ \\
\hline 3 & Block A7-1 & 1.8 & $\sim 21$ \\
\hline
\end{tabular}

For gas migration and accumulation, it started to extract and move from West to East and Southwest to Northeast at the Western part of study area. However, at the Eastern part, gas migrated from the opposite direction, from East to West and South East - North West (Figure 23).

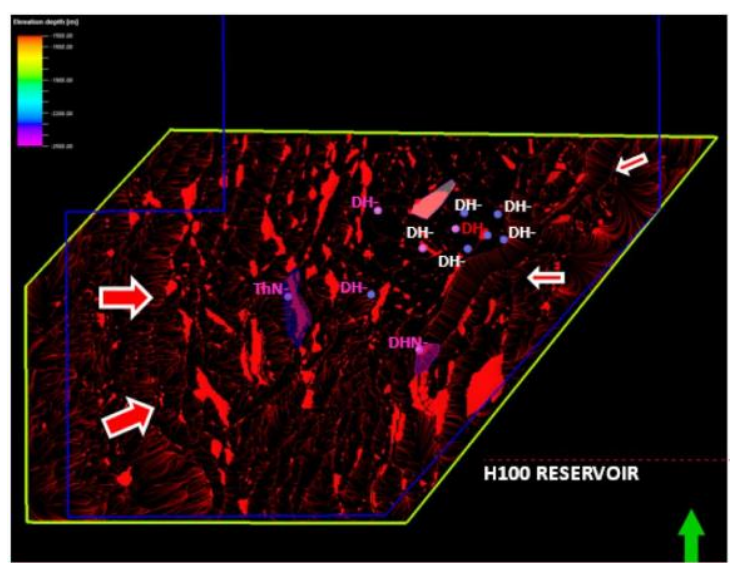

Figure 23. Migration pathway of gas into H100 reservoirs 
The volume of gas accumulated at reservoirs based on the model is assessed as in table below:

\begin{tabular}{|c|c|c|c|}
\hline No & Blocks & $\begin{array}{c}\text { Area } \\
\left(\mathrm{km}^{2}\right)\end{array}$ & $\begin{array}{c}\text { GIIP } \\
(\mathrm{BCF})\end{array}$ \\
\hline 1 & Block A7-1 & 1.8 & $\sim 1.03$ \\
\hline 2 & ThN 1A & 4.07 & $\sim 4.67$ \\
\hline 3 & Block R & 1.53 & $\sim 10.9$ \\
\hline
\end{tabular}

In the case of $\mathrm{H} 80$ reservoir, expulsed oil migrated from the west \& east troughs to DH High by both faults and carrying beds, then trapped in produced reservoirs at DH field (Figure 24). The volume of accumulated oil at reservoirs at blocks which the model results show an estimate as in table below table:

\begin{tabular}{|c|c|c|c|}
\hline No & Blocks & $\begin{array}{c}\text { Area } \\
\left(\mathrm{km}^{2}\right)\end{array}$ & $\begin{array}{c}\text { HCIIP } \\
(\text { MMbbls })\end{array}$ \\
\hline 1 & Block N1-N2 & 4.6 & $\sim 75.8$ \\
\hline 2 & $\begin{array}{c}\text { Block T1+ } \\
\text { Block A4 }\end{array}$ & $0.36+1.4$ & $\sim 19$ \\
\hline 3 & Block A7-1 & 1.8 & $\sim 0.19$ \\
\hline 4 & ThN1A & 4.07 & $\sim 61.4$ \\
\hline
\end{tabular}

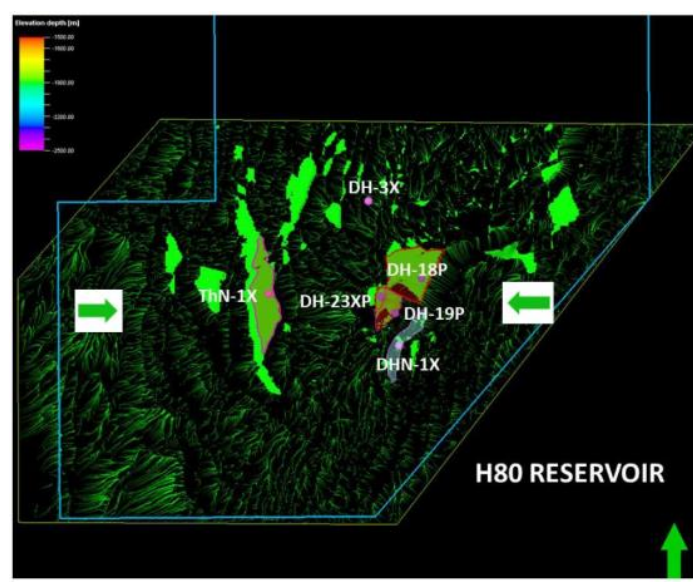

Figure 24. Migration pathway of oil into H80 reservoirs

Gas migrated from the troughs at the West and the East to DH High, accumulated to potential structures, mainly in $\mathrm{ThN}$ area (Figure 25), still not reach DH High yet. The amount of gas accumulation is as in table below:

\begin{tabular}{|c|c|c|c|}
\hline No & Blocks & $\begin{array}{c}\text { Area } \\
\left(\mathrm{km}^{2}\right)\end{array}$ & $\begin{array}{c}\text { GIIP } \\
(\mathrm{BCF})\end{array}$ \\
\hline 1 & Block T1 +Block A4 & $0.36+1.4$ & $\sim 0.03$ \\
\hline 2 & ThN1A & 4.07 & $\sim 0.3$ \\
\hline
\end{tabular}

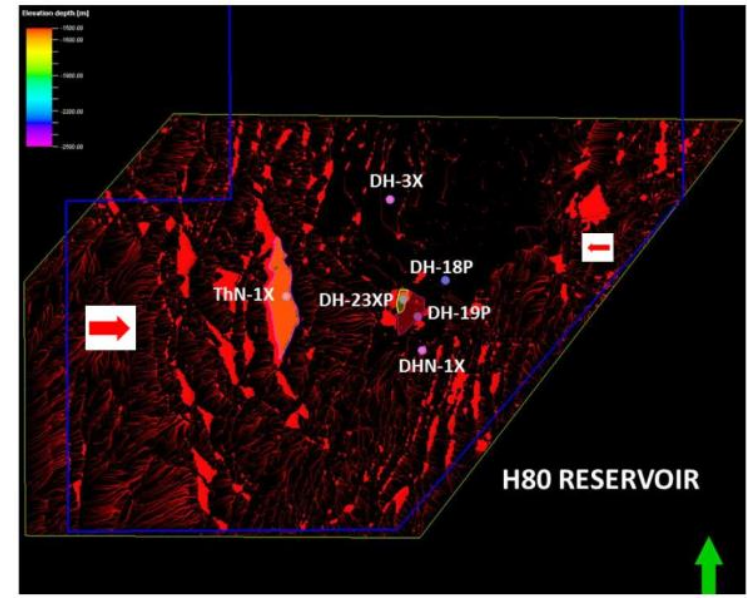

Figure 25. Migration pathway of gas into H80 reservoirs

\subsection{Callbratıon data and sensitlve analysis}

The data of the PSM are calibrated by well data from DH, ThanNong \& DHNam discoveries. Particularly, in the area, there are three main source rocks, the H80-H133 (Lo. Miocene), H133H150 (Lo. Miocene) and H150-H200 (Oligocene). These formations have organic matter content ranging from $0.5 \%$ to $4 \%$, average $2 \div 2.5 \%$, HI from $150 \div 400$, average $250 \mathrm{mg} / \mathrm{g}$, Kerogen mainly types II and III, it produces both oil and gas. The results of the geochemical analysis demonstrate the oil is produced at a depth of 3,300 $\div 3,500 \mathrm{~m}$, the threshold of gas at about $4,800 \div 5,000 \mathrm{~m}$. At present, $70 \%$ volume of $\mathrm{H} 150$ $200 \mathrm{SR}, 50 \%$ volume of $\mathrm{H} 133-150 \mathrm{SR}$, and $30 \%$ volume of H80-H133 SR fallen into the oil window respectively.

To understand the effects of source rock properties, fault seal capacity, this study has been carried out several scenarios as follows: Source rock optimized case: Source rock properties assigned with higher quality of source rock; Fault seal capacity: close and open faults cases.

The high TOC of $2 \%$ is input for sensitive analysis, other boundary conditions such as close fault, reservoir and seal of $\mathrm{H} 100$ remaining the same. The model output is represented in Figure 26. The oil in maximum case is mostly distributed in the North and East matching with the real situations. Nevertheless, gas accumulates in the DH field which should not be. This case gives the result of too much hydrocarbon trapped in structures at DH field, even places found no oil. 


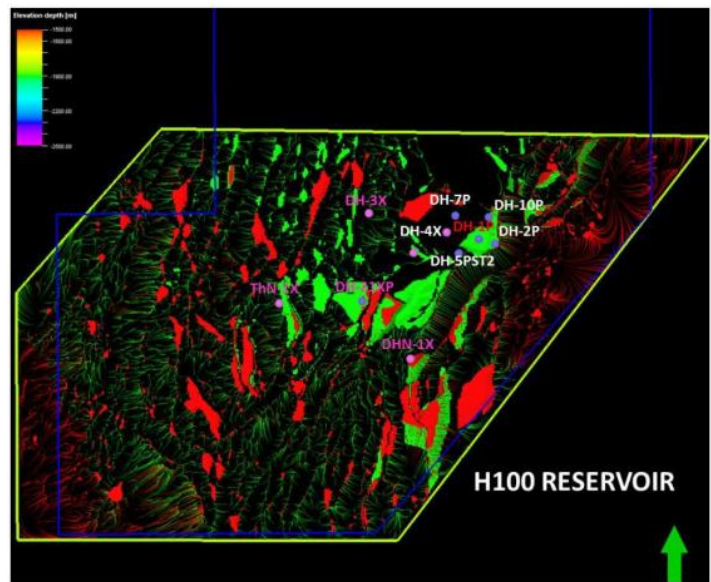

Figure 26. HC volume of maximum case

In case seal of fault (combine with condition of TOC $=1$ ), the model output results in an irrelevance in reality: too much $\mathrm{HC}$ accumulated in outside structures of DH field, whereas, inside the high blocks, where most oil are being produced at the moment, there is very little oil accumulated (Figure 27). On the other hand, the fault is assumed to open (Figure 28); it is too little HC to be accumulated in structures, even places found much oil in reality.

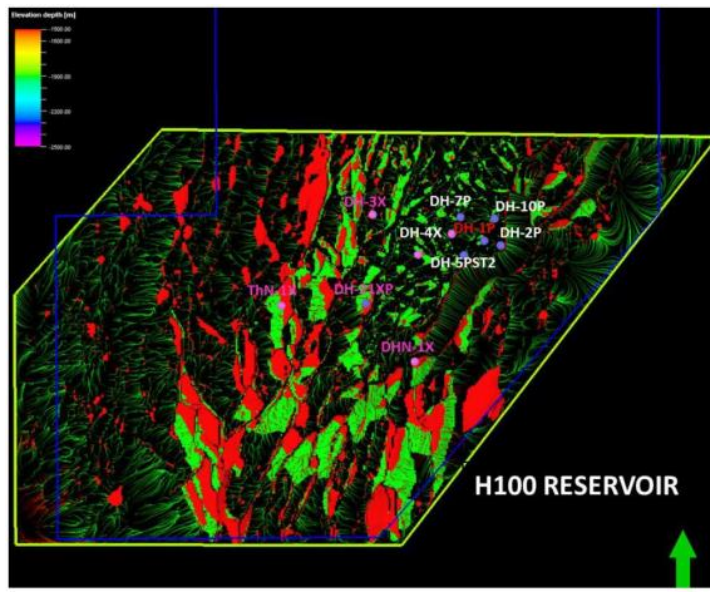

Figure 27. HC accumulation in case of close fault

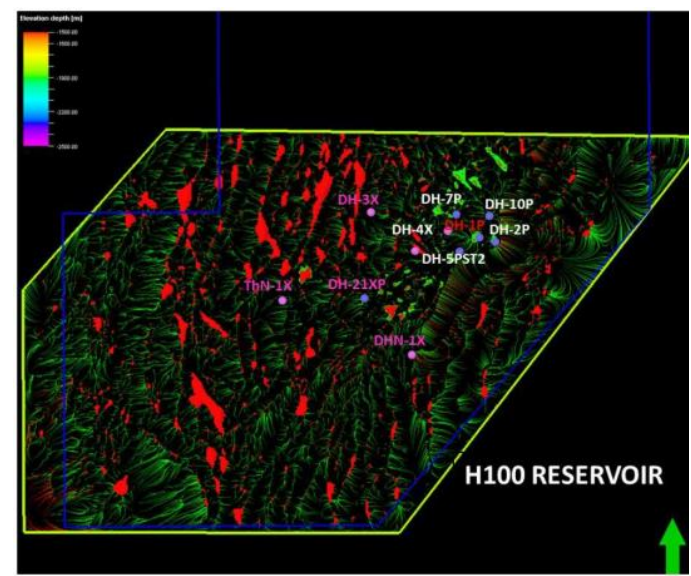

Figure 28. HC accumulation in case of opened fault

\section{CONCLUSIONS AND RECOMMENDATION}

Based on the results of modeling oil and gas potential, the petroleum system within block 05-1 are defined, main source rocks in the study area are H150 shale, H125 shale with TOC 1 and H150 Coal with TOC 47. These source rocks are medium to good potential. At the present time, most of the source rocks are in oil window, while the deep parts are in gas window. At DH field, source rock is in mature stage only. Oil started to be generated in Early Miocene, and started to be expulsed in Late Miocene. Gas started to be generated in Quaternary, about to be expulsed. Oil migrated mainly from the troughs at the West and minorly from the East and South to DH High, accumulated to production reservoirs at $\mathrm{DH}$ field and potential structures outside DH field. Gas started to migrate from West to East and South West to North East at the Western part of study area. However, at the Eastern part, gas migrated from the opposite direction, from East to West and South East - North West. Oil and gas in DH field are either migrated from West, Southwest and East side but not from below source rock.

Uncertainties and recommendation:

Sensitive analyses show more oil in max source rock case: this is unrealistic, not fit with well results. The case of fault closed and open all the time show less oil in the field. Therefore, a 3D model, which allow to model fault properties at different time is recommended. The charge area not cover whole area; hence the study area should be open to adjacent blocks to achieve better and more accurate on source of hydrocarbon migrated to block 05-1a. 


\section{REFERENCES}

[1] PVEP, POC, Internal report, Dec 2015;

[2] Arsalan Zeinalzadeh, Reza Moussavi-Harami, "Basin and petroleum system modeling of the Cretaceous and Jurassic source rocks of the gas and oil reservoirs in Darquain field, south west Iran", http://www.sciencedirect.com/science/article/pii/S187551 0015002887

[3] Petro Vietnam association, "Vietnam Geology and petroleum resources", 2016

[4] The RECTIE, HCM City BK University, final report, "Provision of petroleum systems modeling study services for Dai Hung Nam \& Than Nong discoveries, Nam Con Son Basin, offshore Viet Nam", 2015.

Tran Van Xuan received the B.C. degree in Geological Engineering from Ho Chi Minh City University of Technology - VNU-HCM, Vietnam in 1984 and Ph.D. degree in Geology from Ha Noi University of Mining and Geology, Ha Noi, Vietnam in 2004.

From 1984 to present, he is a Lecturer, Head of Petroleum Geology Department, Faculty of Geology and Petroleum Engineering, Ho Chi Minh City University of Technology - VNU-HCM, Vietnam.

Asst. Prof. Xuan's research interest includes applied petroleum engineering, reservoir engineering, exploration unconventional, water supply technology, waste technology, geotechnical, hydrogeology.

Tran Nhu Huy was born in Greenwich Village, New York, NY, USA in 1977. He received the B.S. and M.S. degrees in aerospace engineering from the University of Virginia, Charlottesville, in 2001 and the Ph.D. degree in mechanical engineering from Drexel University, Philadelphia, $\mathrm{PA}$, in 2008.

From 2001 to 2004, he was a Research Assistant with the Princeton Plasma Physics Laboratory. Since 2009, he has been an Assistant Professor with the Mechanical Engineering Department, Texas A\&M University, College Station. He is the author of three books, more than 150 articles, and more than 70 inventions. His research interests include high-pressure and high-density nonthermal plasma discharge processes and applications, microscale plasma discharges, discharges in liquids, spectroscopic diagnostics, plasma propulsion, and innovation plasma applications. $\mathrm{He}$ is an Associate Editor of the journal Earth, Moon, Planets, and holds two patents.

Dr. Author was a recipient of the International Association of Geomagnetism and Aeronomy
Young Scientist Award for Excellence in 2008, and the IEEE Electromagnetic Compatibility Society Best Symposium Paper Award in 2011.

Nguyen Dinh Chuc received B.S. degree in Petroleum Geology from Ha Noi University of Mining and Geology, Ha Noi, Vietnam in 1999 and M.S. degree in Applied Geophysics from Chiang Mai University, Chiang Mai, Thailand in 2005. He is currently pursuing Ph.D. degree in Petroleum Engineering at Ho Chi Minh City University of Technology - VNU-HCM, Vietnam.

From 2002 to 2007, he worked for PetroVietnam Exploration Production Company as Geophysicist in charged for seismic interpretation supporting for hydrocarbon potential evaluation of blocks in Cuu Long basin. Working as Senior Geophysicist/Team Leader in Exploration Division of PetroVietnam Exploration Production Corporation from 2007 to 2010, he was in charged for QC of seismic interpretation applied in exploration and reservoir geophysics. From 2010 to present, he has been assigned as Deputy Exploration Manager of PVEP POC in charging for exploration activities in block 09-2/09, Cuu Long basin, offshore Vietnam.

Mr. Chuc has over 15-year experience of seismic interpretation, including structural, stratigraphic and reservoir geophysics. He is also experienced in basin analysis, structural and play geology, sequence stratigraphy and sedimentary depositional environment interpretation. He has been a member of SPE, SEG for years.

Nguyen Tuan received the B.C. degree in Geological Engineering from University of Science, VNU-HCM, Vietnam in 2013 and M.St. degree in Petroleum from Ho Chi Minh City University of Technology - VNU-HCM, Vietnam in 2016

Nguyen Xuan Kha Xuan received the B.C. degree in Earth Science from University of Science, VNU-HCM, Vietnam in 2003 and Mst. degree in Geology from University of Science, VNU-HCM, Vietnam in 2003.

Luong Bao Minh received the B.C degree in Petroleum Engineering from the University of Adelaide

Truong Quoc Thanh received the B.C. degree in Petroleum Geology Engineering from Ho Chi 
Minh City University of Technology - VNUHCM, Vietnam, in 2013 and the M.S. degree in Petroleum Engineering from Ho Chi Minh City University of Technology - VNU-HCM, Vietnam, in 2015.

From 2014 to present, he was a Researcher at Petroleum Geology Department, Faculty of Geology and Petroleum Engineering, Ho Chi Minh City University of Technology - VNU-HCM, Vietnam.

Mr. Thanh's research interest includes geophysics, reservoir engineering. 


\title{
Mô hình hóa hệ thống dầu khí trong trầm tích Kainozoi Lô 05-1a, bể Nam Côn Sơn
}

\author{
Trần Văn Xuân, Trần Như Huy, Nguyễn Đình Chức, Nguyễn Tuấn, Thái Bá Ngọc \\ Nguyễn Xuân Khá, Trương Quang Thanh, Phí Hoàng Quang Trung, Lương Bảo Minh
}

Tóm tắt-Trên cơ sở số liệu thăm dò cập nhật, tiềm năng dầu khí lô 05-1a, bể Nam Côn Sơn được đánh giá thông qua tiềm năng đá mẹ; sét, than tuổi Oligocen, Miocen sớm - giữa, xác định tích tụ dầu khí các đối tượng trong Miocen hạ; đánh giá quy mô phân bố (bề dày, tích khối) của lát cắt tầng chứa trong phạm vi nghiên cứu. Kết quả nghiên cứu địa hóa, phân tích mẫu dầu, đá mẹ và mối tương quan đã cho phép phân loại/ so sánh dầu tại sinh với dầu di cư từ nơi khác. Xác lập quy trình mô hình hóa hệ thống dầu khí từ đó xác định quá trình di cư, quy mồ của tích tụ dầu khí, cuối cùng đánh giá độ tin cậy của kết quả. Trong khu vực nghiên cứu đá mẹ chủ yếu là các tập sét $\mathrm{H150}$ và $\mathrm{H} 125$ với TOC xấp xỉ 1 và tập than H150 với TOC xấp xỉ 47. Tiềm năng sinh dầu được xếp hang từ trung bình đến tốt. Vào thời điểm hiện tại, phần lớn đá mẹ rơi vào cửa sổ tạo dầu, phần đáy đã đạt ngưỡng tạo khí. Dầu bắt đầu được hình thành từ Miocene sớm, phóng thích trong Miocene muộn. Khí bắt đầu được hình thành từ Đệ Tứ, và đang bắt đầu phóng thích. Dầu di cư chủ yếu từ các địa lũy ở rìa Tây và một phần từ phía Đông và Nam lền khối nhô của mỏ Đại Hùng. Tại khu vực phía Tây, khí cũng bắt đầu di cư từ Tây qua Đông và từ Tây Nam qua Đông Bắc. Tuy nhiên, tại phần phía Đông thì hướng dịch chuyển hoàn toàn trái ngược. Các yếu tố không chắc chắn đá mẹ có thể sinh lượng dầu lớn hơn nhưng không khớp với kết quả khoan, chưa định lượng với trường hợp đứt gãy kín và hở, như vậy cần phát triển mô hình hệ thống $3 \mathrm{D}$ cũng như nhận diện và so sánh sự khác biệt của đặc điểm sinh dầu giữa bể Nam Côn Sơn với bể Cửu Long.

Tù khóa-Mô hình hóa, minh giải địa chấn, hệ thống dầu khí, di cư, tích tụ dầu khí. 